\title{
RESEARCH OF THE BRIDGE STRUCTURE BY IMPACT-ECHO METHOD
}

\section{ДОСЛІДЖЕННЯ КОНСТРУКЦЇ̈ МОСТА МЕТОДОМ ІМПАКТ-ЕХО}

Orešković Matija, Ph.D. in Engineering, Associate Professor, Cvitković Ivan, mag. ing. traff., Brlek Predrag, Ph.D. in Engineering, Associate Professor, (University North, Varazdin, Croatia), Klymenko Ievgenii, Doctor of Engineering, Professor (Odesa State Academy of Civil Engineering and Architecture, Odesa, Ukraine), Kučina Lucija, bacc. ing. aedif. (University North, Varazdin, Croatia), Krantovska Olena, Ph.D. in Engineering, Associate Professor (Odesa State Academy of Civil Engineering and Architecture, Odesa, Ukraine)

Орешкович Матіа, к.т.н., доц., Цвіткович Іван, магістр, Брлек Предраг, к.т.н., доц. (Північний університет, Вараздін, Хорватія), Клименко Євгеній, д.т.н., проф. (Одеська державна академія будівництва та архітектури, Одеса, Україна), Кучіна Луція, бакалавр (Північний університет, Вараздін, Хорватія), Крантовська Олена, к.т.н., доц. (Одеська державна академія будівництва та архітектури, Одеса, Україна)

This article reflects the results of studies of the operated bridge on the river Mozdernyak in the municipality of Kneginek (Croatia), which was subject to expert analysis of the needs of reconstruction.

In the process of field research of the structures of the considered bridge, the Impact-Echo method was used and at the same time the peculiarities of the method of this method were investigated. In particular, on the basis of the Impact-Echo method, the construction of the old part of the studied bridge was checked, as well as the connection of this old part with the new part of the bridge was checked.

Also, studies on the example of the construction of this bridge found that the acoustic properties of the wall components (brick, block and mortar) are quite similar, that in most cases masonry building elements respond to Echo-Impact as a solid block and this should be taken into account. This method allows you to detect cavities in several walls and assess their scale and impact on the strength of structures.

The use of research equipment provided by the Impact-Echo method allowed to investigate the deposition of concrete in the lower and upper reinforcing zones of the bridge, as well as to determine the existing boundary between the layer of concrete and asphalt.

Thus, the results of the research presented in the article allow to improve the methodology of research of bridge structures by the Impact-Echo method. In addition, expert opinions were made on the condition and prospects of operation of the bridge considered in this article - the bridge structure is in a satisfactory condition, which 
allows its operation. However, after some time it is recommended to repeat the research of the bridge using the method of the Beat-Echo method, with the continuation of the research areas to a new section of the bridge.

У даній статті відображено результати досліджень експлуатованого моста на річиі Моздерняк в общині Кнегінек (Хорватія), який підлягав експертному аналізу щодо потреб проведення реконструкиії.

У процесі виконання натурних досліджень конструкиій розглядуваного моста використовувався метод Удар-Ехо та одночасно досліджувалися особливості методики даного методу. Зокрема, на основі методу Удар-Ехо проводилась перевірка конструкиії старої частини досліджуваного моста, а також здійснювалась перевірка зв'язку иієї старої частини із новою частиною моста. Також дослідженнями на прикладі конструкиії даного моста встановлено, що акустичні властивості компонентів стіни (цегла, блок та розчин) досить подібні, щчо в більшості випадків муровані будівельні елементи реагують на ЕхоУдар як суиільний блок $i$ ие потрібно враховувати у методииі досліджень конструкиій за даним методом. Даний метод дозволяе виявити порожнини у декількох стінах та оцінити їх масштаби і вплив на міцчність конструкцій.

Використання обладнання для досліджень, передбаченого методикою методу Удар-Ехо, дозволило дослідити відкладення бетону на ділянках нижньої та верхньої арматурних зон конструкиії даного моста, а також визначити існуючу межу між шаром бетону та асфальту.

Таким чином, наведені у статті результати проведених досліджень дозволяють удосконалити методику досліджень конструкиій мостів методом Удар-Ехо. Крім того, зроблено експертні висновки про стан та перспективи експлуатачії розглядуваного у даній статті моста - конструкиії моста є у задовільному стані, що дозволяе проводити його експлуатацію. Однак, через деякий час рекомендується повторити досліджень моста з використанням методики методу Удар-Ехо, із продовженням ділянок досліджень на нову секиію моста.

Keywords: Impact-Echo method, bridge, armature, non-destructive testing, delimitations, shock waves, dot raster, frequency.

Ключові слова: метод Удар-Ехо, міст, арматура, неруйнівне випробування, розмежування, ударні хвилі, точковий растр, частота.

\section{Introduction}

\subsection{Impact-echo method}

Impact-Echo is a method for non-destructive testing (NDT) of concrete and masonry structures [1-8 et al.]. The basic researches of a technical condition of various reinforced concrete structures, recommendations on diagnostics are given in our works [4, 5, 9-13, etc.]. Impact-Echo method is based on the use of shock waves that propagate through the medium and are reflected on internal cracks and exterior surfaces [1-3 et al.]. It is used to determine the position and extent of cracks, delamination, cavities, honeycomb-like structures, and separation in flat, reinforced, and subsequent concrete structures. It used for 
slabs, concrete asphalt pavements, columns and beams, hollow cylinders. It provides thickness measurement of concrete slabs with an error of less than $3 \%$ and can locate cavities in the substrate directly from the slab and pavement. The method is most successfully used to identify and quantify suspected problems within the structure, to control quality, such as measuring the thickness of concrete slabs, and in preventative maintenance programs, such as routine evaluation of a bridge deck [3-7 et al.]. In all these situations, Impact-Echo testing has a goal, such as locating cracks, gaps or detachment, measuring thickness, or checking post-fabricated structures for gaps in joint tendons. The Impact-Echo method is very successful in fieldwork [3, 6, 7, etc.]. Impact-Echo testing relies on three basic components: a mechanical impact element capable of producing short-term shocks, the duration of which may change ; surface response receiver/amplifier; a signal analysis system for collecting data for recording, processing and storing wave signals [1-3, 7 , etc.].

Impact-Echo is based on the transient shock waves generated by elastic action. The short-term mechanical impact, produced by slamming a small steel ball onto a concrete or masonry surface, is used to create low impact frequencies that propagate into the structure and are reflected in defects and/or external surfaces [1-3, 5-7, etc.]. The surface displacements caused by reflections of these waves are recorded by the probe, located near the impact [1, 2]. The resulting time-shift, signals are converted to the frequency domain. Frequencyamplitude diagrams (spectra) are obtained with the help of measuring equipment $[7,8]$.

\section{Testing of the bridge structure by Impact-Echo method}

In Impact-echo testing, the number of samples, n, recorded in each test is usually selected as the potential of $2(512,1024,2048$, etc.) The product of the number of samples, $\mathrm{n}$, and the sampling interval, $\Delta \mathrm{t}$, is the length of the record, resp. the total length of time during which the waveform is recorded. The units of the transducer are tightly clamped on the dividing bar, which holds them at a fixed distance, L, separately (usually $300 \mathrm{~mm}$ ), and the aim is to measure as accurately as possible the arrival time of the spherical $\mathrm{P}$ - wave at the two transducers.

If we have time $t_{1}$ and $t_{2}$ then the velocity $P$ of the wave $C_{p}$ is given by equation (1).

$$
c_{p}=\frac{L}{t_{2}-t_{1}}
$$

Is determined by the P-wave speed, to provide a frequency $\mathrm{f}$ measured at the same site as the speed:

$$
f=\frac{0,96 C_{p}}{2 T} \rightarrow T=\frac{0,96 C_{p}}{2 f}
$$


$\mathrm{L}=300 \mathrm{~mm}$ is taken as an example:

$$
\begin{gathered}
t_{2}-t_{1}=75 \mu \mathrm{s} \\
C_{p}=\frac{L}{t_{2}-t_{1}}=\frac{0,3}{0,000075}=4000 \mathrm{~m} / \mathrm{s}
\end{gathered}
$$

After reading $f_{\text {Treading }}=10,3 \mathrm{kHz}$ we get:

$$
T=\frac{0,96 C_{p}}{2 f}=186 \mathrm{~mm}
$$

In June 2017, the bridge under study was expanded [14]. After the visible damage in advance for two years, it was asked to do Impact-Echo test (Fig. 1, $[4,5])$.
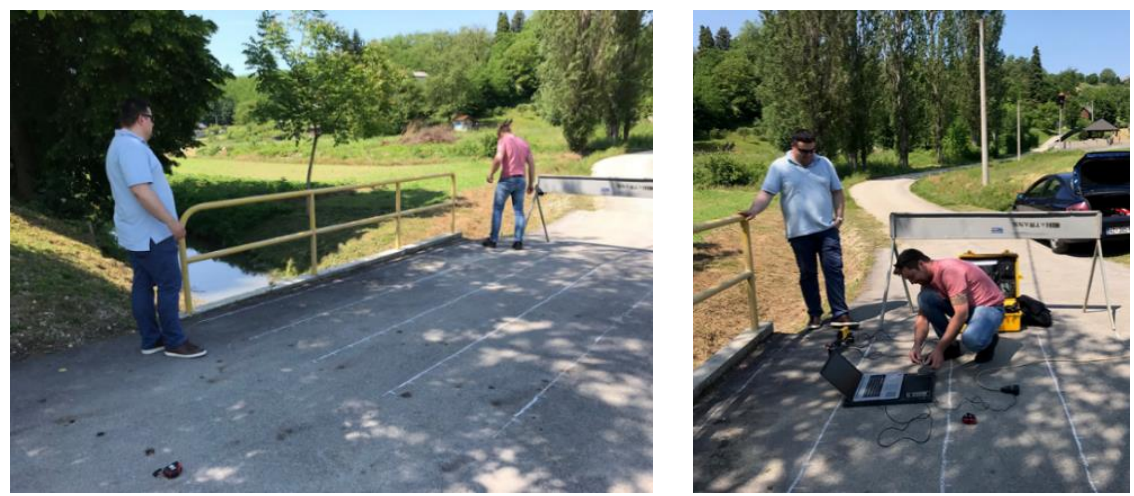

Fig. 1. Preparation for testing by the Impact-Echa method

The bridge is laterally widened and its dimensions are $5.0 \mathrm{~m}$ and $6.0 \mathrm{~m}$ (Fig. 2).

The Impact-Echo method made a check of the construction of the old part of the bridge, as well as of the connection of the old part with the new part [4, 5]. The survey is divided into two sides of the bridge, where the grid of points is 4 x 24 (Fig. 3).

After plotting the point grid, the Impact-Echa settings are set before placing the device on the test surface. The assumed thickness of the asphalt and concrete layer is defined in the program. The wave velocity of the slab is set, and the frequency is $6.3 \mathrm{kHz}$ as the frequency of the concrete layer. The frequencies between the two lines (green and blue), which define the boundaries 
of the layers according to the preset parameters at $6.3 \mathrm{kHz}$ and $12.7 \mathrm{kHz}$, are observed (Fig. 4).

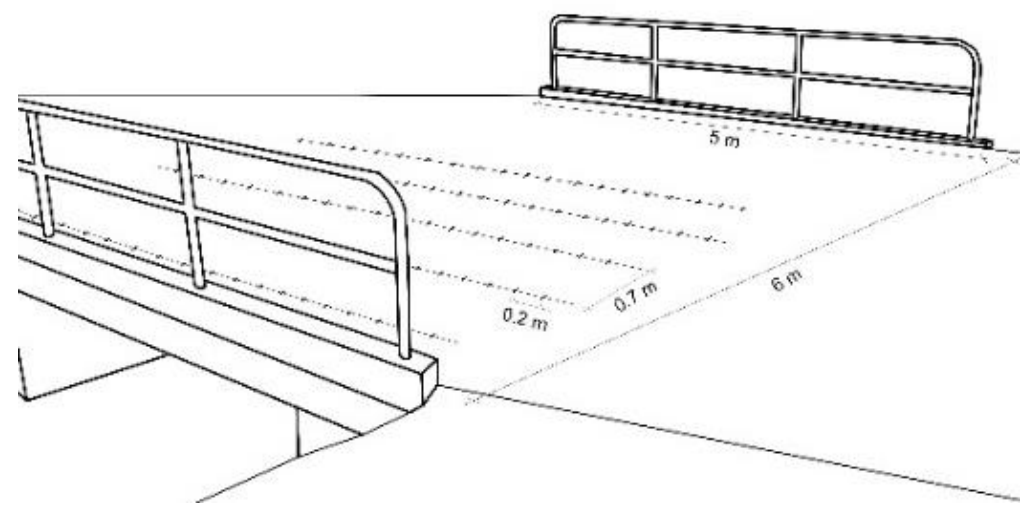

Fig. 2. Bridge dimensions and sketch

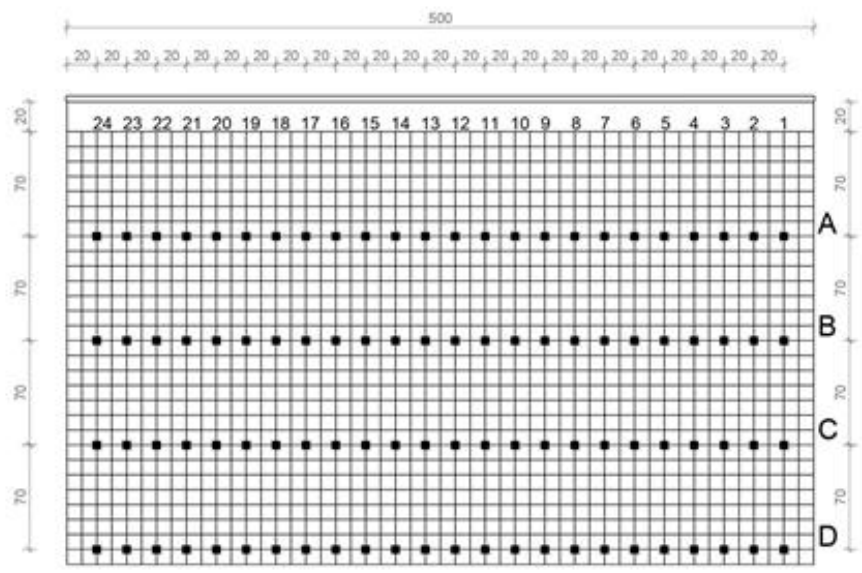

Fig. 3. Point grid

The red line in Fig. 4 indicates the dominant peak. The frequencies between these two lines represent the reflection of the P-wave in the concrete layer. The frequencies to the right represent the reflection of the $\mathrm{P}$-wave within the asphalt layer of the green line.

A frequency of $6.3 \mathrm{kHz}$ is set as the frequency of the concrete layer. The same frequency is at $286 \mathrm{~mm}$ thick, while $315 \mathrm{~mm}$ is the intended thickness. There are two options. At a thickness of $286 \mathrm{~mm}$, there is a crack or 
delamination, while the other possibility is that the thickness of the layer is at that point of the raster (Fig. 5).

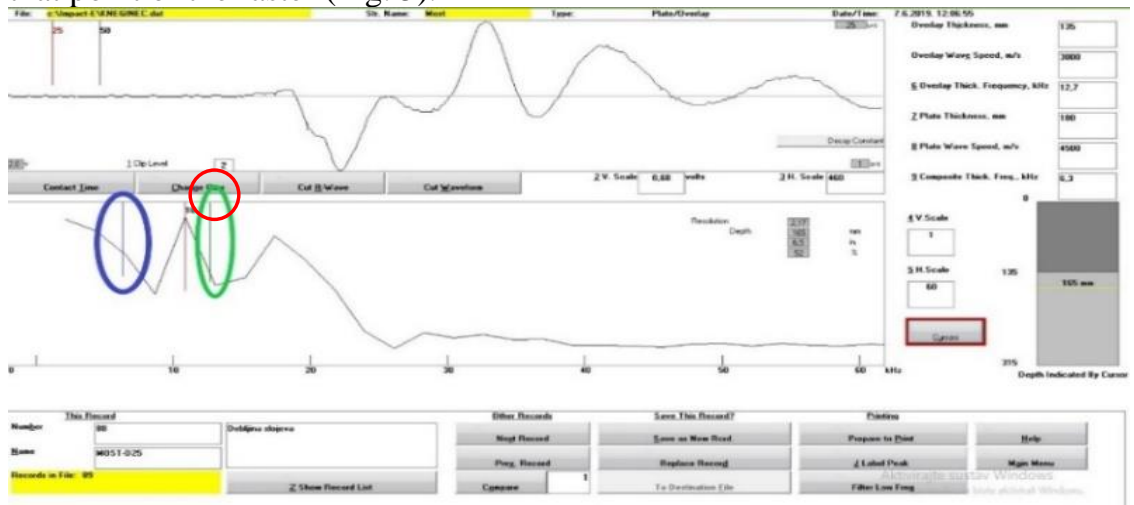

Fig. 4. Impact-echo program (D25)
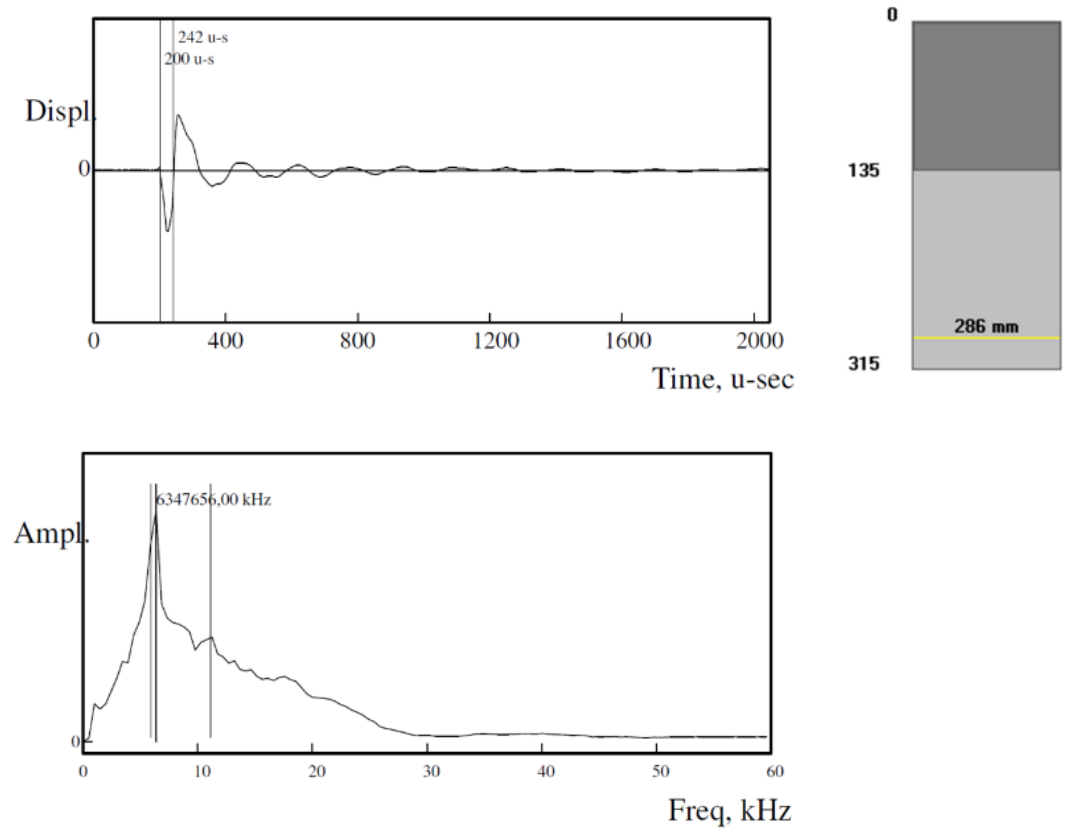

Fig. 5. Test at raster point A3 
The read frequency of $9.8 \mathrm{kHz}$ at the point of raster B12 (Fig. 6) is its dominant peak. A P-wave reflection occurs at a depth of $162 \mathrm{~mm}$, approximately $27 \mathrm{~mm}$ below the junction of the layers, which is approximately the position of the upper reinforcement. Delamination of concrete is indicated indicating any damage or deterioration. The sharp tip of the P-wave reflection from delimitation confirms the original depth.
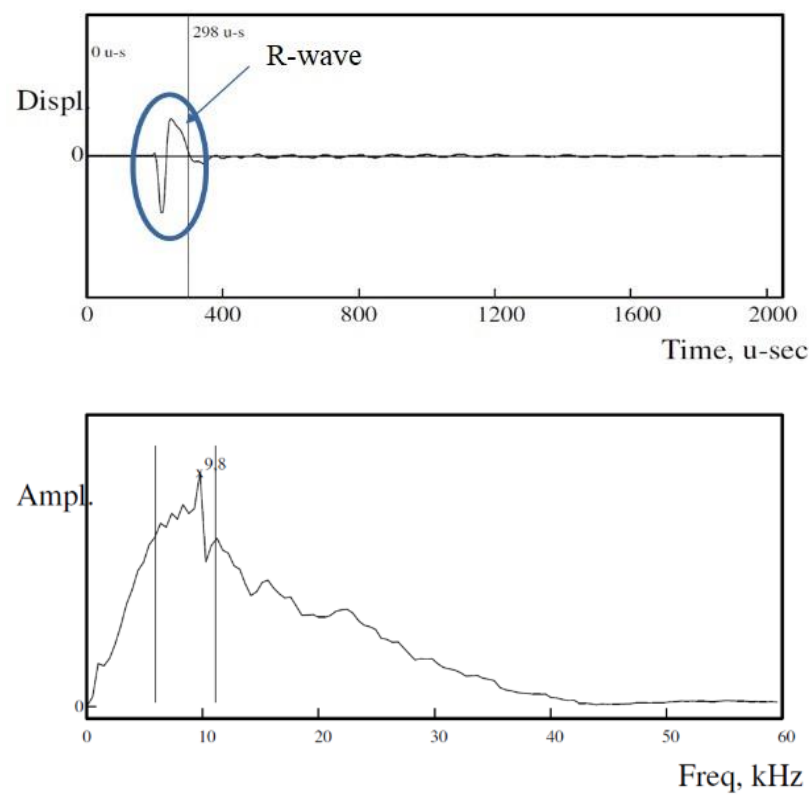

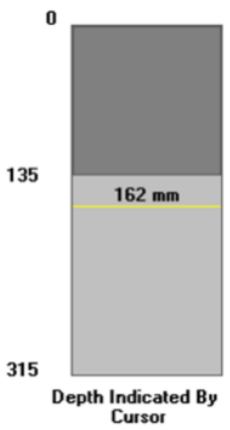

Fig. 6. Test at raster point B12

For the tabular results (Table 1) it was selected an 8-point grid of 89 (Fig. 7), which are located at mutual intervals of $1 \mathrm{~m}$. 


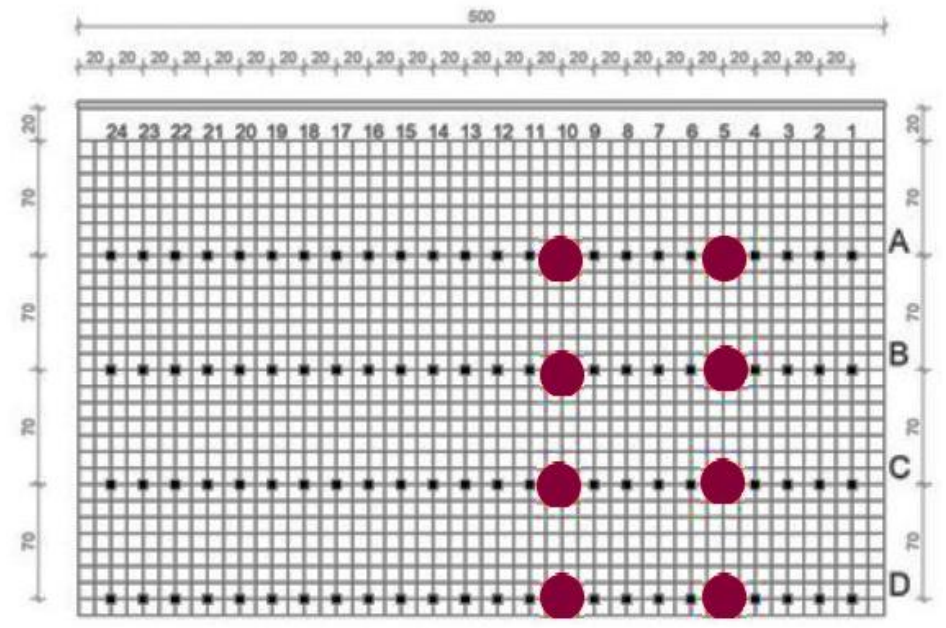

Fig. 7. View of selected 8 raster points

Table 1 . Test analysis

\begin{tabular}{|c|c|c|c|c|c|c|c|}
\hline 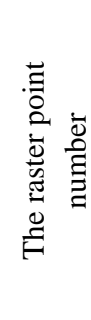 & 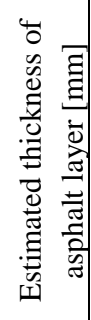 & 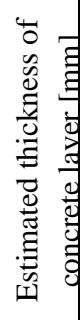 & 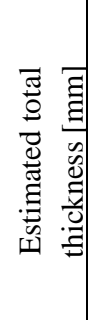 & 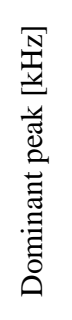 & 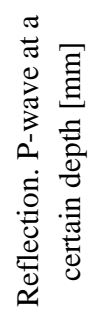 & $\begin{array}{l}\text { Distance from } \\
\text { junction of } \\
\text { layers }\end{array}$ & $\begin{array}{l}\text { Consideration of } \\
\text { possibilities }\end{array}$ \\
\hline A5 & 135 & 180 & 315 & 11,7 & 150 & $\begin{array}{l}\text { approx. } \\
15 \mathrm{~mm} \text { below } \\
\text { the junction of } \\
\text { the layers }\end{array}$ & $\begin{array}{l}\text { Possible placement of upper } \\
\text { reinforcement / delimitation } \\
\text { of concrete }\end{array}$ \\
\hline A10 & 135 & 180 & 315 & 3,9 & I & I & $\begin{array}{l}\text { Inability to get concrete } \\
\text { layer information because } \\
\text { P-waves are not transmitted } \\
\text { through the joint }\end{array}$ \\
\hline & & & & & & $\begin{array}{l}\text { approx. } \\
68 \mathrm{~mm} \text { below }\end{array}$ & $\begin{array}{l}\text { Delimination of concrete / } \\
\text { reinforcement area }\end{array}$ \\
\hline
\end{tabular}




\begin{tabular}{|c|c|c|c|c|c|c|c|}
\hline B10 & 135 & 180 & 315 & 8,7 & 203 & $\begin{array}{l}\text { the junction of } \\
\text { the layers }\end{array}$ & $\begin{array}{l}\text { Inability to get concrete } \\
\text { layer information because } \\
\text { P-waves are not transmitted } \\
\text { through the joint }\end{array}$ \\
\hline C10 & 135 & 180 & 315 & 4,3 & 303 & $\begin{array}{l}\text { / } \\
\text { approx. } \\
168 \mathrm{~mm} \\
\text { below the } \\
\text { junction of the } \\
\text { layers }\end{array}$ & $\begin{array}{l}\text { Inability to get concrete } \\
\text { layer information because } \\
\text { P-waves are not transmitted } \\
\text { through the joint } \\
\text { A crack or delimination / } \\
\text { thickness of a layer at that } \\
\text { point of the raster }\end{array}$ \\
\hline D10 & 135 & 180 & 315 & 13,0 & 131 & $\begin{array}{l}\text { approx. } 4 \mathrm{~mm} \\
\text { above the } \\
\text { junction of the } \\
\text { layers } \\
\text { approx. } \\
30 \text { mm below } \\
\text { the junction of } \\
\text { the layers }\end{array}$ & $\begin{array}{l}\text { Delimination of concrete / } \\
\text { joint of two layers } \\
\text { Possibility of positioning } \\
\text { the upper armature }\end{array}$ \\
\hline
\end{tabular}

After the table analysis (data Table 1 et $[4,5]$ ), a graphical analysis was performed (Fig. 8), which included the data of 17 raster points, the depth of Pwave reflection as well as the distance from the junction of the layers. The green line indicates the critical depths of P-wave reflection, while the blue line indicates the depths that follow the asphalt layer. We can conclude that at critical depths the reflection of the P-wave is due to damage in the reinforcement. 


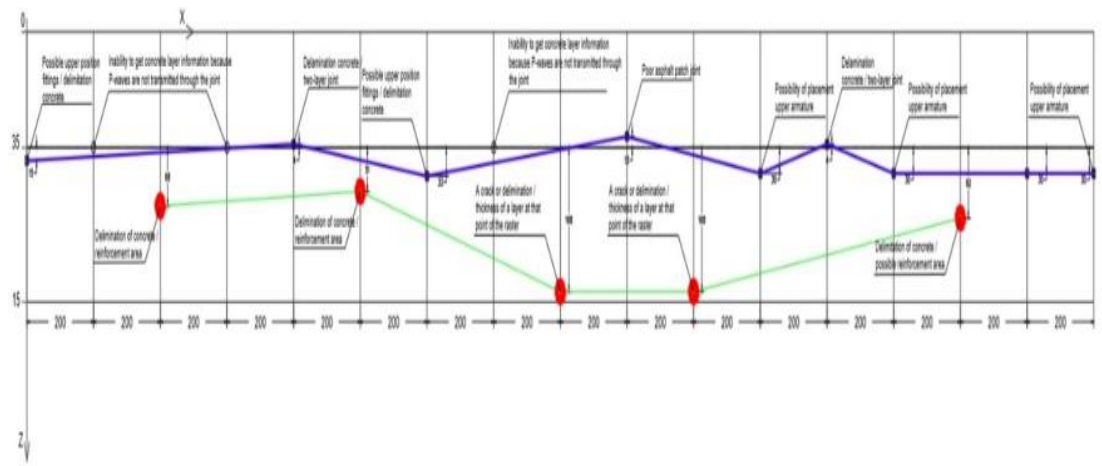

Fig. 8. Longitudinal cross-section of the bridge with the concrete delamination and possible damage to the reinforcement (red dots) and a realistic concreteasphalt joint line (blue line)

\section{Conclusion}

By analyzing the Impact-Echo method, and examining it using the same method, we can come to several important conclusions. The acoustic properties of the wall components (brick, block, and mortar) are similar enough that in most cases the masonry building elements respond to the Impact-Echo as a continuous unit. For example, a single brick wall made up of brick and mortar can be treated as a slab for the purpose of Impact-echo testing. The cracks that appear in the joints have no effect on the brick response effect.The cracks that appear in the joints of the bearing can disrupt reaction, but the effects of this response are highly localized and resemble those of a panel. They can reveal gaps in the joints of the walls that are filled with mortar. It can be injected into voids cells block wall brick or mortar. They can detect cavities in the joints collar multiple walls. By selecting a longer time (more than $30 \mu \mathrm{s}$ ), core walls (where the core area is less than $25 \%$ of the brick surface) can be successfully tested by the Impact-Echo method. The cores cause a measurable shift with respect to the thickness of the brick but do not prevent the detection of cavities in multiple walls. On the example of the Mozdernjak bridge extension, delaminations in concrete were found in the areas of the lower and upper reinforcement zones and a real boundary between the concrete and the asphalt layer was detected. Delaminations indicate extensions of the area around the reinforcement, suggesting rusting of the steel and thus internal damage to the structure. Generally speaking, the situation on the bridge in question is not alarming and as such, it is still usable for normal exploitation. After a while, it is recommended to repeat the bridge test, this time with the extension to a new section with relative control of the old already tested section. 


\section{References}

1. ASTM C1383-15. Standard Test Method for Measuring the P-Wave Speed and the Thickness of Concrete Plates Using the Impact-Echo Method, ASTM International, West Conshohocken, PA, 2015. URL: http://www.astm.org/cgi-bin/resolver.cgi?C1383-15

2. Sansalone M. J., Streett W. B. Impact-Echo: Nondestructive Evaluation of Concrete and Masonry. - Bullbrier Press, 1997. - 339 pp.

3. Schubert F., Köhler B. Ten Lectures on Impact-Echo // Journal of Nondestructive Evaluation. - 2008, 27 (1), pp. 5-21. DOI: 10.1007/s10921-008-0036-2.

4. Orešković M., Cvitković I., Brlek P., Klymenko Ie., Kučina L., Krantovska O. Examination of the bridge on the Mozdernjak stream in the municipality of Kneginec (Croatia) // Problems of integrated city development: Collection of abstracts International scientific and practical conference of scientists and students. Lutsk, Ukraine, 2931.01.2020. [Electronic resource] - Lutsk: Lutsk NTU - KNUCA, 2020. - pp. 57-60. URL: https://konf-mbg.wixsite.com/lntu-bci-mbg-2020.

5. Orešković M., Krpan L., Brlek P., Maršanić R., Kaniški G. Eksploatacija konstrukcije; Ispitivanje mosta na potoku Mozdernjak u općini Kneginec // Ceste 2020. Rovinj, Hrvatska, 10-13.03.2020. - Rovinj, Hrvatska, 2020. - p. 131-142.

6. Muhammad Tariq A. Chaudhary. Effectiveness of Impact Echo testing in detecting flaws in prestressed concrete slabs. - Construction and Building Materials. 2013, 47. - pp. 753-759. DOI: 10.1016/j.conbuildmat.2013.05.021.

7. Otero R., Sulbarán G., Moreno E. Impact-Echo Technique to Assess Concrete Structures. - NDT.net Journal. 2016, 21 (5). - pp. 1-12. URL: https://www.ndt.net/search/docs.php3?id=19109

8. Impact-Echo Instruments. Field Instruments for Nondestructive Evaluation of Concrete and Masonry. - LLC, Ithaca, New York, USA. URL: https://www.indiamart.com/proddetail/impact-echo-systems-9804497291.html

9.Orešković M., Klymenko I., Aniskin A., Kozina G: Analysis of Damaged Concrete Columns of Circular Cross-Section. - Tehnički vjesnik. 2018, 25 (2). - pp. 337343.

10. Volchuk V., Klymenko I., Kroviakov S., Orešković M. Method of material quality estimation with usage of multifractal formalism. - Technical Journal. 2018, 12 (2). - pp. 93-97.

11. Krantovska O., Petrov M., Ksonshkevych L., Orešković M., Synii S., Ismailova $\mathrm{N}$. Numerical simulation of the stress-strain state of complex-reinforced elements. - Technical Journal. 2019, 13 (2). - pp. 110-115.

12. Orešković M., Zadravec V., Kos Ž., Klimenko E.V. Structural reliability and evaluation of current state of construction. - Technical Journal. 2015, 9 (4). - pp. 426431.

13. Orešković M. Stress-strain state and strength of damaged compressed reinforced-concrete elements of circular cross section. Dis.... cand. tech. sc. Speciality 05.23.01 - building constructions, building and structure. - OSACE. - Odesa, 2015, 214 pp.

14. Proširenje mosta na potoku Mozdernjak [Electronic resource]. URL: http://www.kneginec.hr/vijesti/gospodarstvo/838-prosirenje-mosta-na-potokumozdernjak.html 